\title{
MEMORY IN DISCOURSE: APPROACHING CONFLICTING CONSTELLATIONS OF HOLOCAUST AND POSTCOLONIAL MEMORY IN GERMANY
}

\author{
LIANE SCHÄFER \\ OSNABRÜCK UNIVERSITY
}

\begin{abstract}
In today's Germany, the memory of the Holocaust has become institutionalized. However, its institutionalization should not be mistaken for stability. In fact, Holocaust memory has been and still is questioned and contested. At the same time, a global phenomenon, postcolonial memory, is receiving increased attention in Germany. As postcolonial memory is better understood, new questions are arising about Germany's memory culture in the twenty-first century. Precisely because of Germany's experience with National Socialism, the memory of colonialism exists in a memory space that is heavily influenced by discussions of the Holocaust. The memories of the two phenomena appear in constellations that conflict with each other. In this paper, I address the two conflicting constellations of Holocaust memory and postcolonial memory, and propose a discursive perspective on Germany's memory culture. Analyzing a national memory culture as a creation of discourse provides an opportunity to resolve the argumentative standoff between Holocaust memory and postcolonial memory, and instead put German memory culture itself at the center of criticism.
\end{abstract}

Keywords: Holocaust memory; postcolonial memory; discourse; Germany; Achille Mbembe DOI: $10.14712 / 23363231.2021 .4$

Liane Schäfer is a PhD candidate at the Institute of Social Sciences at University Osnabrück. Address correspondence to Universität Osnabrück, Institut für Sozialwissenschaften, Seminarstraße 33, D-49074 Osnabrück. E-mail: lischaefer@uni-osnabrueck.de.

The author would like to thank her two anonymous reviewers for their comprehensive review and instructive comments. 


\section{Introduction}

In 2020, a public dispute sparked by a postcolonial historian and political scientist, Achille Mbembe, sharpened the conflict between the constellations of Holocaust memory and postcolonial memory in Germany. ${ }^{1}$ While postcolonial memory has just recently received broader attention in German academia and public, the memory of the Holocaust has long been perceived as an integral part of German memory culture. ${ }^{2}$ Recurrent speeches by politicians, such as those of German Federal President Frank-Walter Steinmeier given in commemoration of the 75th anniversary of the end of the World War II in 2020, illustrate how the memory of the Holocaust functions in Germany. Steinmeier said:

"There can be no deliverance from our past. For without remembrance we lose our future. ... Anybody who cannot bear this, who demands that a line be drawn under our past, is not only denying the catastrophe that was the war and the Nazi dictatorship. They are also devaluing all the good that has since been achieved and even denying the very essence of our democracy."3

Since the late 1990s, the German model for coming to terms with National Socialist crimes has been transnationalized. ${ }^{4}$ On the contrary, postcolonial

1 Regarding the debate about Achille Mbembe see Natan Sznaider, "The Summer of Discontent: Achille Mbembe in Germany," Journal of Genocide Research, December 4, 2020, doi: $10.1080 / 14623528.2020 .1847862$.

2 By using the term Holocaust instead of Shoah, I am adopting the terminology preferred by Mirjam Tünschel. Shoah is a biblical term, the Hebrew word for catastrophe. As such, it began to appear in German discourse in the 1980s. The term Holocaust appeared earlier, in the 1950s, in connection with the Anglo-American debate on the meaning of National Socialism and Auschwitz. A Greek word, its literal meaning is "totally burnt." As it gained more and more popularity, the term Holocaust lost its specificity. For that reason, its continued use has drawn criticism. Nevertheless, its use is well-established internationally, which is why I use it in this paper. See Mirjam Tünschel, Erinnerungskulturen in der deutschen Einwanderungsgesellschaft. Anforderungen an die Pädagogik (Oldenburg: BIS-Verlag, 2009), 23-24. See also Astrid Messerschmidt, Bildung als Kritik der Erinnerung. Lernprozesse in Geschlechterdiskursen zum Holocaust-Gedächtnis (Frankfurt a. M.: Brandes \& Apsel, 2003).

3 Frank-Walter Steinmeier, "Federal President Frank-Walter Steinmeier on the 75th anniversary of the liberation from National Socialism and the end of World War II in Europe at the Central Memorial of the Federal Republic of Germany to the Victims of War and Tyranny (Neue Wache) in Berlin on 8 May 2020," official website of German Federal President, May 8, 2020, https: //www. bundespraesident.de/SharedDocs/Downloads/DE/Reden/2020/05/200508-75-Jahre-EndeWKII-Englisch.pdf?_blob=publicationFile.

4 Here, I refer in particular to the process of the transnationalization of the memory of the Holocaust. See, for example, Daniel Levy and Natan Sznaider, "Memory Unbound: The Holocaust and 
memory almost simultaneously went through a process of domestication into the German space. Beginning with a genuinely global perspective that addresses the violent aftermath of colonialism, postcolonial memory is more and more finding a home in Germany. Discussions are ongoing about the need for an official apology for the genocide of the Herero and Nama peoples in Germany's former colony of German South-West Africa, and are only one prominent example of an increasing focus on Germany's colonial crimes. ${ }^{5}$ While this postcolonial process of reappraisal is still in full swing, the memory of colonialism is coming more often into conflict with the memory of the Holocaust in Germany. The above-mentioned public dispute about the words of Achille Mbembe is the most prominent and wide-ranging debate so far.

In this paper, I will examine the conflicting constellations of Holocaust memory and postcolonial memory in Germany. I will also ask how a discursive perspective might contribute to better understanding of both constellations. As I have mentioned, German memory culture is strongly shaped by remembrance of the Holocaust. Therefore, in the first part of this paper I review Germany's process of coming to terms with its National Socialist past. In the second part, I address postcolonial memory in Germany. Then, using the Causa Mbembe as an example, I illustrate how the constellations of the two memory forms conflict. At that point I also differentiate the problems that arise from the conflict between the specific forms the constellations of Holocaust memory and postcolonial memory take in the German context. Finally, I explain the potential of a discursive perspective for analyzing the conflicting constellation in a way that does not pit both memory forms against each other, but instead critically questions the discourse of German memory culture as a whole.

Before I examine the conflicting constellations of Holocaust and postcolonial memories, I want to comment briefly on the concept of memory with which I align myself in this paper.

the Formation of Cosmopolitan Memory," European Journal of Social Theory 5, No. 1 (February 2002): 87-106, doi: 10.1177/1368431002005001002. A study by Susan Neiman, Learning from the Germans: Race and the Memory of Evil (New York: Farrar, Straus and Giroux, 2019) is a current example of a comparison of the German Holocaust memory with memory discourses in other countries.

5 German South-West Africa is the name for today's Namibia. It was officially been under German colonial occupation from the 1880s until 1915. See Jürgen Zimmerer and Joachim Zeller, eds., Völkermord in Deutsch-Südwestafrika. Der Kolonialkrieg (1904-1908) in Namibia und seine Folgen (Augsburg: Weltbild, 2014). 
First, when I use the term memory, I refer to a social process that epitomizes the needs and values of the contemporary society involved. Thus, whereas history seeks to create an accurate image of past events, remembering is a "present-day operation of compiling available data," as Astrid Erll describes it. "Versions of the past change with each recall according to the changed present." ${ }^{6}$ Remembering and memory must be understood as dynamic social phenomena. Hence, according to Aleida Assmann, one can conceive of the relation between history and memory as follows: "History turns into memory when it is transformed into forms of shared knowledge and collective identification and participation."7

Secondly, like Assmann, when I speak of memory and remembering I am focusing on the notion of memory as a form of shared collective knowledge and identification. Collectively shared memories do not require personal experience of a historical event. Instead, they are socially mediated and transgenerational. Collectively shared memories are materialized in museums, rituals, and education, and through individual participation and constant repetition. Thus, I am not focusing here on the bottom-up process by which individuals remember a certain historical event, but rather on how "collective units such as institutions, states and nations" shape memory within the public space, as Assmann puts it. ${ }^{8}$

Thirdly, even though I examine the interplay between institutionally anchored forms of Holocaust memory and collective forms of postcolonial memory, against the background of German national memory culture, I do not consider a memory culture to be a fixed, homogenous thing. In the words of Aleida Assmann, it needs to be understood as a contested "public social arena" in which institutionalized collective memories often confront non-institutionalized collective memories.

6 Astrid Erll, Kollektives Gedächtnis und Erinnerungskulturen. Eine Einführung (Stuttgart: J. B. Metzler, 2017), 6.

7 Aleida Assmann, "Memory, Individual and Collective," in The Oxford Handbook of Contextual Political Analysis, ed. Robert E. Goodin and Charles Tilly (New York: Oxford University Press, 2006), 210-226.

8 Ibid, 215. Even though I focus on the collective side of memory I do not understand the personal side of memory as a separate process from its social side. Here I align myself with the tradition of the sociologist Maurice Halbwachs, who pointed out that each individual memory is influenced by its social surroundings. See, for example, the first chapter of Maurice Halbwachs, On Collective Memory, ed. Lewis A. Coser (Chicago and London: The University of Chicago Press, 1992).

9 Assmann, "Memory, Individual and Collective," 219. 


\section{The Emergence and the Fragility of Holocaust Memory in Germany}

The term Holocaust has at least two meanings. One meaning refers to the historical event itself, namely the systematic extermination of Jewish people in Germany's Nazi era. The second meaning has grown beyond the historical event itself. Using the Nazi Holocaust as a point of reference, the word has come to refer to any event of outstanding malevolence, not only in Germany, but internationally. ${ }^{10}$

The memory of the Holocaust has not only transcended national borders but has also passed through various phases within Germany. In order to understand the dynamics of the conflict between Holocaust memory and postcolonial memory, I must first shed light on some of the stages through which Holocaust memory has gone in Germany since the end of the Nazi era in 1945. However, the following applies only to the process in West Germany after World War II. The way West German society dealt with the Nazi past was different from that of East German society. ${ }^{11}$

At first, remembrance of the Holocaust was not central to the memory of the Nazi era. Only with increasing distance in time from the Holocaust has its memory and the historical awareness of it grown in non-Jewish German society. ${ }^{12}$ The immediate response of German society at large to the systematic extermination of Jewish people must be classified as a non-response. This collective silence is what Jörn Rüsen describes as the foundation stone of the new institutions of West Germany. ${ }^{13}$ In general, the desire to re-integrate with the West and the reorientation towards a democratic political system made adapting more important than moral reappraisal. ${ }^{14}$

A generational change in the 1960 s, from the so-called war and reconstruction generation to the postwar generation, caused a paradigm shift from silence to speaking out about the Nazi era in general and the Holocaust in particular. As

${ }^{10}$ Levy and Sznaider, "Memory Unbound," 88; Ulrike Jureit and Christian Schneider, Gefühlte Opfer. Illusionen der Vergangenheitsbewältigung (Stuttgart: Klett-Cotta, 2010), 12.

11 Wolfgang Meseth, "Education After Auschwitz in a United Germany: A Comparative Analysis of the Teaching of the History of National Socialism in East and West Germany," European Education 44, No. 3 (2012): 13-38, doi: 10.2753/EUE1056-4934440301. See also Neiman, Learning from the Germans.

12 Jörn Rüsen, "Holocaust-Erfahrung und deutsche Identität. Ideen zu einer Typologie der Generationen," in Die Gegenwart der Psychoanalyse - die Psychoanalyse der Gegenwart, ed. Werner Bohleber and Sibylle Drews (Stuttgart: Klett-Cotta, 2002), 95-106.

13 Ibid., 98.

14 Aleida Assmann, Das neue Unbehagen an der Erinnerungskultur. Eine Intervention (München: C. H. Beck, 2016), 49. 
society began to tolerate moral criticism, the Nazi era and the Holocaust became fixed historical events of outstanding negativity. By putting the historical events at the center of controversy, the members of the postwar generation were not only able to face up to the violent crimes committed by their parents, but also to view themselves as different from the previous generation. The Nazi era and the Holocaust became negative identity-forming historical events and integral parts of modern German identity. The long traditions of German history no longer served as the sole foundation of German collective identity. Instead, the new generation adopted universal norms and values. In summary, the Nazi era and the Holocaust formed the negative pole of collective German identity while universal norms and values symbolized its positive pole. ${ }^{15}$ The implicit equivalence between speaking out and morality was the foundation of a discourse that organized itself around the question of guilt. That discourse was not restricted to the private sphere of the family but also manifested itself in strong political protest against the recently established state of West Germany. ${ }^{16}$

The concept of moral responsibility for the German past continued to develop in the 1960s, 1970s, and 1980s. The use of guilt in order to break the war and reconstruction generation's silence caused a lasting shift in how Germany dealt with its past. What was formerly seen as positive - forgetting the Nazi era and the Holocaust in order to integrate the West German state into the democratic project of the West - was increasingly perceived as repression and a sign that the past was being minimized. As opposed to the war and reconstruction generation, the postwar generation focused its attention on the Jewish experience as victims of the Nazi era. Occasionally, that focus resulted in strong identification with Jewish victimhood as the wartime generation's strategy of silence broke down. ${ }^{17}$

By the time of the third generation after World War II, however, the war narrative was transformed by analysis of the role of the perpetrator. Since the 1980s, the grandchildren of the war and reconstruction-generation have more and more often included the historical context and their own family biographies in their discussion of the Nazi era and the Holocaust. ${ }^{18}$ Thus, the 1980s

15 Rüsen, "Holocaust-Erfahrung und deutsche Identität," 99-101.

16 Assmann, Das neue Unbehagen an der Erinnerungskultur, 50.

17 Rüsen, "Holocaust-Erfahrung und deutsche Identität," 101. Ulrike Jureit and Christian Schneider even go so far as to describe the German memory culture of the twentieth century as being characterized by identification with victimhood as a means of seeking redemption from moral guilt for the Holocaust. See Jureit and Schneider, Gefühlte Opfer, 10-11.

18 Rüsen, "Holocaust-Erfahrung und deutsche Identität," 101. See also Assmann, Das neue Unbehagen an der Erinnerungskultur, 51. 
marked a second important turning point for Germany's memory culture. Even the term "memory culture" itself - in German, Erinnerungskultur - originated in the 1980s. ${ }^{19}$ It had its genesis in the discussion about the Nazi period and the Holocaust. In Germany, there is a strong symbolic connection between the term memory culture and the historical epoch between 1933 and 1945. Several significant events accompanied the ever-growing focus on the question of responsibility for the crimes committed during the Nazi era. The Historikerstreit of 1986/87 was a conflict between several German historians, which turned on the answer to the question of the uniqueness of the Holocaust. It showed the change that the meaning of the Holocaust was undergoing in German memory culture. The German historian Ernst Nolte interpreted the Holocaust not as an independent historical phenomenon of outstanding importance, but rather as a reaction to Soviet terror. ${ }^{20}$ His position was strongly opposed by the German philosopher and sociologist Jürgen Habermas, who accused Nolte of relativizing the Holocaust. ${ }^{21}$ The Holocaust ultimately became the central element of German memory culture in the 1980s. It did not gain its significance as the greatest violent crime of the twentieth century until 40 years after the end of World War II. ${ }^{22}$

Holocaust memory continued to develop in the 1990s. With the reunification of East and West Germany at the beginning of the 1990s, remembrance of the Holocaust became more and more institutionalized. The formerly unspeakable and unthinkable - the Holocaust - became utterable. The memory of the formerly unspeakable became an integral part of state, public and academic attention in the newly unified federal republic. ${ }^{23}$ According to Aleida Assmann, the talk of moral guilt that had dominated public discourse since the 1960s turned into a recognition of historical responsibility for the past. The memory of the Holocaust in Germany today is shaped by an ethical imperative that manifests itself in the sentence "Remember in order not to repeat the past" - an ethical imperative that has now transcended national borders. ${ }^{24}$

19 Assmann, Das neue Unbehagen an der Erinnerungskultur, 190.

${ }^{20}$ Ernst Nolte, "Vergangenheit, die nicht vergehen will. Eine Rede, die geschrieben, aber nicht gehalten werden konnte," in "Historikerstreit." Die Dokumentation der Kontroverse um die Einzigartigkeit der nationalsozialistischen Judenvernichtung, ed. Rudolf Augstein et al. (München: Piper, 1987), 39-47.

${ }^{21}$ Jürgen Habermas, "Eine Art Schadensabwicklung. Die apologetischen Tendenzen in der deutschen Zeitgeschichtsschreibung," in "Historikerstreit." Die Dokumentation um die Einzigartigkeit der nationalsozialistischen Judenvernichtung, ed. Rudolf Augstein et al. (München: Piper, 1987), 62-76.

22 Assmann, Das neue Unbehagen an der Erinnerungskultur, 190-191.

${ }^{23}$ Ibid., 67-68. See also Messerschmidt, Bildung als Kritik der Erinnerung, 32-34.

24 Assmann, Das neue Unbehagen an der Erinnerungskultur, 66. 
However, this same German memory culture, internationally perceived as a model for reconciling with the past, is increasingly running into contradictions. First, despite all efforts to come to terms with the past, antisemitic incidents are increasing in Germany. In 2019, the German federal government's Commissioner for the Fight against Antisemitism went so far as to advise Jews not to display religious symbols such as the kippah in public. ${ }^{25} \mathrm{Sec}-$ ondly, even though the public narrative of the Holocaust tells successful stories of coming to terms with the past, privately the situation is totally different. In 2002, interviews with Germans from three different generations revealed a strong discrepancy between public and private memory. The interviewees' stories about the Nazi period were characterized by narratives of the victimization and heroic actions of their own ancestors. ${ }^{26}$ Although some members of the third generation after World War II embraced a coming to terms with the Nazi past in their own family history, progress in that direction later came to a standstill. Just recently, Samuel Salzborn has argued that a real, self-critical reappraisal of the Nazi era still has not taken place in Germany. Instead, the self-image that Germans have internalized is dominated by a notion of collective innocence. ${ }^{27}$

In fact, the ambivalence of an institutionalized, yet contested Holocaust memory has expressed itself in numerous public debates from the 1990s onwards. On the one hand, the self-image of collective innocence has repeatedly been challenged on different occasions. The publication in 1996 of the book Hitler's Willing Executioners: Ordinary Germans and the Holocaust, by Daniel Goldhagen, ${ }^{28}$ was criticized by academics but was read with great interest by the German public. An exhibition in 1995 at the Hamburg Institute for Social Research about the crimes of the German Wehrmacht brought the mass participation of ordinary Germans in National Socialism to the fore and shed light on the responsibility and involvement of the broad German population in the crimes of National Socialism. ${ }^{29}$ On the other hand, a 1998 debate between

25 “Kann Juden nicht empfehlen, überall die Kippa zu tragen,” Zeit Online, May 25, 2019, https:// www.zeit.de/gesellschaft/zeitgeschehen/2019-05/judenfeindlichkeit-antisemit-felix-klein-kippa.

${ }^{26}$ Harald Welzer, Sabine Moller, and Karoline Tschuggnall, "Opa war kein Nazi." Nationalsozialismus und Holocaust im Familiengedächtnis (Frankfurt a. M.: Fischer, 2002), 205-210.

27 Samuel Salzborn, Kollektive Unschuld. Die Abwehr der Shoah im deutschen Erinnern (Leipzig: Hentrich \& Hentrich, 2020).

28 Daniel Jonah Goldhagen, Hitler's Willing Executioners. Ordinary Germans and the Holocaust (New York: Knopf, 1996).

29 Ruth Wittlinger, German National Identity in the Twenty-First Century. A Different Republic After All? (Basingstoke: Palgrave Macmillan, 2010), 26-27. For a detailed overview and classification 
the German writer Martin Walser and the head of the Central Council of Jews in Germany, Ignatz Bubis, took the contested Holocaust memory in another direction. Walser sparked a controversy with his acceptance speech for a peace prize awarded by the German Publishers \& Booksellers Association. Among other controversial statements in his speech, he described the planned construction of a national Holocaust Memorial in Berlin as the "monumentalization of shame." 30 Bubis accused Walser of aligning himself with demands for putting an end to the memory of the Holocaust and National Socialism. The debate was shaped less by a desire to deconstruct the narrative of the innocent German than by concern that the memory of the Holocaust would be trivialized.

The debate about the collective innocence of ordinary Germans and demands to shelve the memory of the Holocaust and National Socialism are still active today. Recent surveys show that many Germans, despite the dominant public narrative, still continue to underestimate their ancestors' participation in National Socialist crimes. ${ }^{31}$ Such surveys also reveal a significant number of people who agree with the statement that Germans should abandon the focus on the memory of the Holocaust and National Socialism. ${ }^{32}$ The recurring debate exemplifies the contradictions and struggle that continue around the memory of the Holocaust. Astrid Messerschmidt describes this duality between an institutionalized yet contested Holocaust memory as the "fragility" of Holocaust memory. ${ }^{33}$

This short ride through the history of Germany's Holocaust memory shows that remembering and forgetting are not one-dimensional, but rather complex social processes. In fact, remembering and forgetting should not be misunderstood to be opposites, but rather as processes that are entangled. As Maja

of the controversy about the Wehrmacht exhibition, which contradicted the narrative of the innocent German, see Maja Zehfuss, Wounds of Memory: The Politics of War in Germany (New York: Cambridge University Press, 2007), 129-141.

${ }^{30}$ Martin Walser, "Dankesrede von Martin Walser zur Verleihung des Friedenspreises des Deutschen Buchhandels in der Frankfurter Paulskirche am 11. Oktober 1998. Erfahrungen beim Verfassen einer Sonntagsrede," https://hdms.bsz-bw.de/frontdoor/deliver/index/docId/440/file/walserRede.pdf.

31 "Die Haltung der Deutschen zum Nationalsozialismus. Januar 2020. Ergebnisse einer repräsentativen Erhebung. Tabellarische Auswertung im Auftrag von DIE ZEIT," 43, https://www.zeit. de/2020/19/zeit-umfrage-erinnerungskultur.pdf.

32 Astrid Schläffer, "Ein Viertel will Abschluss mit NS-Zeit," ZDF, December 05, 2020, https://www. zdf.de/nachrichten/politik/holocaust-umfrage-ns-zeit-100.html.

${ }^{33}$ Messerschmidt, Bildung als Kritik der Erinnerung, 32-36. 
Zehfuss puts it: "In order to forget, one has to remember in the first place. Conversely, in order to remember, one has to forget." 34

The central point behind the debates about Holocaust memory is actually not that the National Socialist past should be remembered, but how to remember it. ${ }^{35}$ Accordingly, the ethical imperative to accept historical responsibility - to remember, in order not to repeat the past - must be understood not in a literal but in a metaphorical sense. The National Socialist past will most likely not repeat itself in the same way, but an active decision to remember the Holocaust and National Socialism acknowledges historical responsibility in the present for the past. As I have pointed out earlier, the act of remembering serves a purpose for contemporary society. Even though the Holocaust is in fact not forgotten, the ethical imperative that the participants in the memory culture accept their historical responsibility still remains at the center of a process of negotiation.

Hereinafter, I will take a closer look at postcolonial memory in Germany, which has recently received more and more attention.

\section{Postcolonial Memory in Germany}

In summer 2020, the social movement Black Lives Matter sparked a broad public and political debate about racism and colonialism in Germany. In one of her speeches Aminata Touré, a member of the Green faction and the Vice-President of the Schleswig-Holstein state parliament, pointed at the German participation in the European colonial project, in which Germany was not only a global colonial power for 30 years, but especially contributed intellectually to the development and spread of racist ideologies:

The current debate about racism in Germany cannot be understood if one does not know about Germany's colonial crimes. ... A debate about colonialism can only be carried out if it names those who suffered from these inhuman crimes and who still feel its effects today - Black people. In order to understand that racism is an ideology which was scientifically developed here in Germany, we have to look back. It is not just about a racist moment, but about colonial crimes that still have an impact today. ... The search for an evolutionary theoretical argument for the subordination

${ }^{34}$ Zehfuss, Wounds of Memory, 63.

35 Ibid., 63-64. 
of Black people within the human species began with the German exploitation of the African continent. It was Kant, Hegel and Winckelmann who, among others, created a pseudoscientific basis for all this. ${ }^{36}$

The involvement of Germany in colonialism has never been completely forgotten, especially in academia. Nevertheless, in the historiography, the German colonial project has long been portrayed as motivated mainly by material and economic interests. Cultural factors were mostly ignored. ${ }^{37}$ As for the public and political sphere, and for the vast majority of society, there has for a long time been no critical reflection on colonialism. When it is discussed, the conversation often relativizes the commission of crimes in the colonies. ${ }^{38}$

Postcolonial memory nowadays presents a counter-narrative to this relativizing discourse. It can be classified as both a research field and a claim that the attention of memory must be shifted to colonialism and the racism that globally prevailed in that epoch. It is an impetus for investigating the consequences of the colonial past and its racism for the present global order. ${ }^{39}$ Postcolonial thinking can be found worldwide today not only in academia, but also in social movements and in public and political debates. In a sense, the statement by Aminata Touré quoted above represents this postcolonial thinking and refers to a multitude of claims, ideas, and knowledge of postcolonial memory. The beginning of postcolonial thinking is often dated back to the 1980s, as a form of intellectual "countertelling" in the field of critical anglophone literary and cultural studies. Since then, the application and analysis of postcolonial thinking has become

36 "Schwarze Akteur*innen bei der Aufarbeitung von Kolonialismus einbinden," official website of Aminata Touré, June 18, 2020, https://aminata-toure.de/schwarze-akteurinnen-bei-der-aufarbeitung-von-kolonialismus-einbinden/. For an analysis of Kant's and Hegel's pseudoscientific argumentation on the differences between human 'races,' see chapters four and ten in Emmanuel Chukwudi Eze, Race and the Enlightenment. A Reader (Malden, Oxford, Victoria: Blackwell Publishing, 1997).

37 Sebastian Conrad, Deutsche Kolonialgeschichte (München: C.H. Beck, 2012), 12.

38 Kien Nghi Ha, "Postkoloniale Kritik als politisches Projekt," in Postkoloniale Soziologie. Empirische Befunde, theoretische Anschlüsse, politische Intervention, ed. Julia Reuter and Paula-Irene Villa (Bielefeld: transcript, 2010), 259-280.

39 I use postcolonial thinking and postcolonial memory interchangeably because the act of remembering in postcolonial thinking is highly intertwined with topics such as the history of colonialism and the legacy of racism. In a sense, because it is a central tenet of the postcolonial perspective that the colonial past still shapes our present, it would be misleading to separate the theoretical claims of postcolonial thought from the act of remembering. Instead, postcolonial memory must be understood as a central theme of the postcolonial idea itself. The broader field of memory studies has started to adopt postcolonial thinking. See, for example, Dirk Göttsche, ed., Memory and Postcolonial Studies: Synergies and New Directions (Oxford: Peter Lang, 2019), doi: https:// doi.org/10.3726/b14024. 
highly interdisciplinary and heterogeneous. ${ }^{40}$ In this paper, I will outline some of the basic assumptions of postcolonial thinking that underlie postcolonial memory practices.

In a nutshell, Leela Gandhi defines postcolonial thinking as "a disciplinary project devoted to the academic task of revisiting, remembering and, crucially, interrogating the colonial past." 41 In this regard, the prefix "post" can cause some confusion. Indeed, postcolonial thinking does not start at a point after the official end of the colonial age. Rather, in the words of Leela Gandhi, it tries to emphasize how "a relationship of reciprocal antagonism and desire between coloniser and colonised" 42 continues to have aftereffects in the present. Postcolonial thinking not only focuses on the formerly colonized societies, but also analyzes the effects of colonialism on the European colonizing countries, which is a very central point. ${ }^{43}$ Postcolonial thought understands that history is not a linear process and focuses on the contradictions inherent in the process of decolonization. One of the central contradictions of postcolonial thinking, for example, is the ambiguity of modernity and the Enlightenment. Very often, modernity is imagined as an intra-European achievement, while at the same time the idea that formerly colonized countries should be measured by that standard is implicitly assumed. This Eurocentrism ignores the fact that it was colonialism's scientifical invention of the races that made it possible to imagine Europe as being of higher value. To this day, the violent side of the supposedly rational and enlightened modern Europe has been ignored or relativized. ${ }^{44}$ Postcolonial thinking makes it possible to criticize the way in which colonialism is remembered and to point out the relativization of colonial violence in the global and local contexts. The many postcolonial initiatives that have been

40 Tanja Ernst, "Postkoloniale Theorie und Politische Praxis: Die Dekolonisierung Boliviens," PROKLA. Zeitschrift für kritische Sozialwissenschaft 40, No. 158: 49-66, doi: 10.32387/prokla. v40i158.400. Ina Kerner, Postkoloniale Theorien zur Einführung (Hamburg: Junius, 2012), 10. See also the publications of Homi K. Bhabha, Edward W. Said, and Gayatri Chakravorty Spivak, whose ideas form the basis for much of postcolonial research: Homi K. Bhabha, The Location of Culture (London: Routledge, 1994); Edward W. Said, Orientalism (New York: Vintage Books, 1979) Gayatri Chakravorty Spivak, A Critique of Postcolonial Reason. Toward a History of the Vanishing Present (Cambridge: Harvard University Press, 1999).

${ }^{41}$ Leela Gandhi, Postcolonial Theory. A Critical Introduction (New York: Columbia University Press, 2019), 4.

42 Ibid.

${ }^{43}$ María do Mar Castro Varela and Nikita Dhawan, Postkoloniale Theorie. Eine kritische Einführung (Bielefeld: transcript, 2020), 15-16.

${ }^{44}$ Enrique Dussel, "Europe, Modernity, and Eurocentrism," Nepantla: Views from South 1, No. 3 (2000): 465-478. 
spreading through German civil society since the 2000s are good examples of postcolonial memory practice. Among other things, those initiatives are calling for streets and places that honor German colonial rulers to be renamed in order to honor instead people who fought against slavery or racism in former German colonies or within Germany itself. ${ }^{45}$

In addition to that very concrete application of postcolonial thinking, scholars have repeatedly pointed out Germany's intellectual colonial legacy. The link between Germany as the center of the Enlightenment and its significant contributions to the ideology of racism as a justification for European colonialism supported Germany's and other powers' involvement in the colonizing movement. ${ }^{46}$ Because postcolonial memory shifts the focus onto the societies of the former colonizing countries, it is possible to deconstruct the current forms of racism in Germany and demonstrate how racist ideas of inferiority and superiority still persist. ${ }^{47}$

Black people and People of Color have long fought against racism in Germany. ${ }^{48}$ In doing so, they have relied on the intellectual works of anti-colonial activists that were the precursors to postcolonial memory. ${ }^{49}$ Black people and People of Color had to confront racism every day. Because they could not find any representations of their own histories and experiences in Germany's public space, they reclaimed their histories by creating empowering structures of their own. In 1986, the same year that the Historikerstreit took place, May Ayim and Katharina Oguntoye, along with others, published a feminist anthology by and for German Black people and People of Color in order to share their realities with white Germans. ${ }^{50}$ Ayim and Oguntoye met in a university seminar led by Audre Lorde, a scholar, writer and activist from the United States who started a visiting

${ }^{45}$ See, for example, a very recent project on the nationwide mapping of the German colonial legacy: "Tear This Down. Kolonialismus jetzt beseitigen," https://www.tearthisdown.com/de/, accessed January 26, 2021.

46 See, for example, the chapters about Immanuel Kant and Georg Wilhelm Friedrich Hegel in Eze, Race and the Enlightenment. See also Nikita Dhawan, "Affirmative Sabotage of the Master's Tools: The Paradox of Postcolonial Enlightenment," in Decolonizing Enlightenment. Transnational Justice, Human Rights and Democracy in a Postcolonial World, ed. Nikita Dhawan (Opladen: Barbara Budrich, 2014), 19-78.

47 See, for example, Kien Nghi Ha, "Macht(t)raum(a) Berlin - Deutschland als Kolonialgesellschaft," in Mythen, Masken und Subjekte: kritische Weißseinsforschung in Deutschland, ed. Maureen Maisha Eggers et al. (Münster: Unrast, 2009), 105-117. See also Natasha A. Kelly, Afrokultur. "der raum zwischen gestern und morgen" (Münster: Unrast, 2016).

48 See Kien Nghi Ha, "Postkoloniale Kritik als politisches Projekt" as well as Kelly, Afrokultur.

${ }^{49}$ Castro Varela and Dhawan, Postkoloniale Theorie, 23-28.

${ }^{50}$ Katharina Oguntoye, May Ayim and Dagmar Schultz, Farbe bekennen: Afro-deutsche Frauen auf den Spuren ihrer Geschichte (Berlin: Orlanda, 1986). 
professorship at the Free University of Berlin in 1984. ${ }^{51}$ Today, postcolonial thinking builds on the struggles and the work of Black people and People of Color in Germany. The fact that the realities of Black Germans and German People of Color have still received scant attention in German public debates is an opportunity to claim the importance of postcolonial memory culture. Similar to discussions on Holocaust memory, postcolonial memory is asking questions about both what to remember (colonialism and its connection to racism) and how to remember, by countering opposing relativizing narratives.

\section{Conflicting Constellations of Holocaust Memory and Postcolonial Memory}

In the following section I illustrate some of the areas of conflict between Holocaust memory and postcolonial memory. Since the beginning of the 2000s, points of friction between the two memories have repeatedly arisen in academia and public debate.

Postcolonially inspired historiographers started to emphasize the parallels between German colonialism and National Socialism at the beginning of the 2000s. ${ }^{52}$ The theses of the postcolonial historian Jürgen Zimmerer sparked a lot of discussion in particular. Focusing on the genocide of the Herero and Nama committed by Germans in the former colony of German South-West Africa, Zimmerer argued that colonial violence and the violence of the National Socialist era were similar and just different in degree, but not in their structure..$^{53}$ Other

51 “Mit 'Farbe bekennen' machten May Ayim und Katharina Oguntoye die Lebensrealität afrodeutscher Frauen zum Thema," Bayerischer Rundfunk, April 21, 2020, https://www.br.de/radio/ bayern2/sendungen/zuendfunk/farbe-bekennen-von-may-ayim-und-katharina-oguntoye-100. html.

52 See, for example, Jürgen Zimmerer and Joachim Zeller, Genocide in German South-West Africa. The Colonial War of 1904-1908 and its Aftermath (London: Merlin Press, 2008); Jürgen Zimmerer, "Nationalsozialismus postkolonial. Plädoyer zur Globalisierung der deutschen Gewaltgeschichte," Zeitschrift für Geschichtswissenschaft 57, No. 6 (2009): 529-548; Konstant Kpao Sarè, "Abuses of German Colonial History: the Character of Carl Peters as Weapon for völkisch and National-Socialist Discourses: Anglophobia, Anti-Semitism, Aryanism," in German Colonialism and National Identity, ed. Michael Perraudin and Jürgen Zimmerer (New York: Routledge, 2001), 160-172; Jürgen Zimmerer, Von Windhuk nach Auschwitz? Beiträge zum Verhältnis von Kolonialismus und Holocaust (Berlin: LIT, 2011); Mark Terkessidis, Wessen Erinnerung zählt? Koloniale Vergangenheit und Rassismus heute (Hamburg: Hoffmann und Campe, 2019).

53 Jürgen Zimmerer, "Holocaust und Kolonialismus. Beitrag zu einer Archäologie des genozidalen Gedankens," in Von Windhuk nach Auschwitz? Beiträge zum Verhältnis von Kolonialismus und Holocaust, ed. Jürgen Zimmerer (Berlin: LIT, 2011), 140-171. 
researchers strongly opposed his idea of a structural identity between colonialism and National Socialism and pointed out fundamental differences between them. ${ }^{54}$ This discussion took place at the beginning of the 2000s. It tended to focus on questions of historical fact and not particularly on the postcolonial views that underlay Zimmerer's work. The increasingly broader acceptance of postcolonial thinking within German academia has been met with general and systematic criticism of it. Good examples of this can be found in the work of Steffen Klävers, who recently examined and criticized postcolonial approaches to historiography, and also in the contributions of Ingo Elbe, who analyzes and criticizes postcolonial approaches to philosophy and the social sciences. Both authors see the roots of the problems with postcolonial thinking in the fact that antisemitism is often subsumed under racism and thus the special factors that led to the Holocaust are minimized. ${ }^{55}$

Some postcolonial scientists note that the level of awareness of the Holocaust that prevails in Germany does not exist for colonial violence. ${ }^{56}$ This view draws on the work of anti-colonial intellectuals like Aimé Césaire. In a German publication on postcolonial approaches to political science, Aram Ziai used a quote from Césaire to point out that approaching the Holocaust from a purely intra-European perspective is problematic because it fails to recognize that human lives were already being sacrificed much earlier during colonialism. Ziai adopts a theoretical postcolonial perspective in which the fading memory of colonial violence is seen as a form of "colonial hypocrisy" and the "application of different ethical standards." 57

${ }^{54}$ See, for example, contributions written by Birthe Kundrus as well as Stephan Malinowski and Robert Gerwarth. Birthe Kundrus, "Kontinuitäten, Parallelen, Rezeptionen. Überlegungen zur 'Kolonialisierung' des Nationalsozialismus," Werkstattgeschichte, No. 43 (2006): 45-62; Stephan Malinowski and Robert Gerwarth, "Der Holocaust als 'kolonialer Genozid'? Europäische Kolonialgewalt und nationalsozialistischer Vernichtungskrieg," Geschichte und Gesellschaft, No. 33 (2007): 439-466; Robert Gerwarth and Stephan Malinowski, "Hannah Arendt's Ghosts: Reflections on the Disputable Path from Windhoek to Auschwitz," Central European History 42, No. 2 (2009): 279-300, doi: 10.1017/S0008938909000314.

55 Steffen Klävers, Decolonizing Auschwitz? Komparativ-postkoloniale Ansätze in der Holocaustforschung (Berlin: De Gruyter, 2019) and Ingo Elbe, “'... it's not systemic.' Antisemitismus im akademischen Antirassismus," in Irrwege. Analysen aktueller queerer Politik, ed. Till Randolf Amelung (Berlin: Querverlag, 2020), 224-260.

56 Joachim Zeller, "Decolonization of the Public Space?" in Hybrid Cultures - Nervous States: Britain and Germany in a (Post)Colonial World, ed. Ulrike Lindner et al. (2011), 65-88, doi: https:// doi.org/10.1163/9789042032293_005. See also Jacob Emmanuel Mabe, "Criticism of Colonialism and the Colonial Memory Work in Germany,” Philosophy Study 9, No. 6 (2019): 310-317, doi: 10.17265/2159-5313/2019.06.002.

57 Aram Ziai, "Einleitung: Unsere Farm in Zhengistan. Zur Notwendigkeit postkolonialer Perspektiven in der Politikwissenschaft," in Postkoloniale Politikwissenschaft. Theoretische und empirische Zugänge, ed. Aram Ziai (Bielefeld: transcript, 2016), 11-24. 
In light of the clear points of friction between postcolonial memory and Holocaust memory, some studies in areas such as social science, cultural science, and educational science are trying to evaluate the intersection of antisemitism and racism. ${ }^{58}$

The debate within academia is also taking place more and more often in the German public space. Especially the German genocide of the Herero and Nama and the demands of those peoples' descendants for an official apology from the German state have been discussed by the public and politicians now for years. In 2018, they resulted in Germany returning human remains of Herero and Nama individuals held in hospitals, museums, and universities. ${ }^{59}$ Overall, the German colonial past is increasingly receiving a critical re-evaluation, which manifests itself in manifold conversations about returning looted colonial property exhibited in German museums. ${ }^{60}$ One event in particular fueled a broad public debate about the intersection of Holocaust memory and postcolonial memory in the spring of 2020. As this public debate exemplifies the complicated relationship between the memories of the Holocaust and Germany's colonial legacy, I will take a closer look at that incident.

At the center of the turmoil lies the invitation of the renowned Cameroonian postcolonial historian and political scientist Achille Mbembe as keynote speaker for the Ruhrtriennale, an international arts festival in the German federal state of North Rhine-Westphalia that is a major German cultural event. The so-called Causa Mbembe raised important questions about the tension between Holocaust memory and postcolonial memory. It began with an open letter signed by a Free Democratic Party (FDP) member of the state parliament of North Rhine-Westphalia, Lorenz Deutsch, in March 2020. Therein, he demonstrated Mbembe's association with the Palestinian-led Boycott, Divestment, and Sanctions (BDS) movement that Germany classifies as antisemitic. ${ }^{61}$ Moreover,

58 See, for example, Sabine Schiffer and Constantin Wagner, Antisemitismus und Islamophobie: Ein Vergleich (Wassertrüdingen: HWK, 2009); Astrid Messerschmidt, "Postkoloniale Erinnerungsprozesse in einer postnationalsozialistischen Gesellschaft - vom Umgang mit Rassismus und Antisemitismus," Peripherie 28, No. 109-110 (2008): 46-60; Claudia Bruns, "Antisemitism and Colonial Racism. Transnational and Interdiscursive Intersectionality," in Racisms Made in Germany, ed. Wulf D. Hund, Christian Koller, and Moshe Zimmermann (Münster: LIT, 2011), 99-121.

59 "Germany returns human remains from Namibia genocide," Deutsche Welle, August 29, 2018, https://www.dw.com/en/germany-returns-human-remains-from-namibia-genocide/a-45268717.

${ }^{60}$ Barbara Weber, “Debatte um Restitution kolonialer Kunst," Deutsche Welle, January 24, 2019, https: / www.deutschlandfunk.de/provenienzforschung-debatte-um-restitution-kolonialer-kunst.1148.de.html?dram:article_id=439063.

${ }^{61}$ In his essay on the Causa Mbembe, Natan Sznaider explains the BDS movement as following: “'Boycott, Divestment and Sanctions,' [is] a loose global movement asking for a cultural, academic, economic, and political boycott against Israel. It was founded by various Palestinian orga- 
Deutsch characterized some sentences in Mbembe's publications as relativizing the Holocaust. Deutsch's open letter was addressed to the director of the Ruhrtriennale festival. ${ }^{62}$ He referred to a resolution of the German Federal Parliament passed in 2019 that condemned the BDS movement and another of the state parliament of North Rhine-Westphalia passed in 2018 that prohibited financial and any other support for BDS-related events. ${ }^{63}$ The Ruhrtriennale festival was ostensibly subject to those resolutions because it relies on state funding. This clash between governmental and cultural institutions illustrated how previously subtle conflicts could break out into a public dispute that ultimately took on a life of its own. The discussion came to the fore of the public agenda when the German federal government's Commissioner for the Fight against Antisemitism, Felix Klein, joined Deutsch in his critique. ${ }^{64}$ Mbembe's invitation as speaker thus became a political issue..$^{65}$

To start with, two tendencies can be identified in the debate about Mbembe's invitation. One position can be described as opposition to antisemitism whereas the other one can be described as opposition to racism. While Mbembe's critics pointed out a structural blind spot for antisemitism in postcolonial research, his defenders identified a structural blind spot for racism in German society. ${ }^{66} \mathrm{~A}$ third position can be identified as well and described as an extension

nizations. Many supporters of Israel claim that it is an antisemitic movement. For critics of Israel it is an anti-colonial movement. For many Jews and supporters of Israel, the term 'boycott' itself provokes associations connected to anti-Jewish sentiments, especially in Germany," Sznaider, "The Summer of Discontent."

${ }^{62}$ Lorenz Deutsch, "Antisemitismus keine Plattform bieten. Offener Brief," official homepage of Lorenz Deutsch, March 24, 2020, https://www.lorenz-deutsch.de/antisemitismus-keine-buehne-bieten $/ 2234 /$.

63 "Der BDS-Bewegung entschlossen entgegentreten - Antisemitismus bekämpfen," Dokumentations- und Informationssystem für Parlamentarische Vorgänge, May 15, 2019, https://dip21. bundestag.de/dip21/btd/19/101/1910191.pdf; "In Nordrhein-Westfalen ist kein Platz für die antisemitische BDS-Bewegung," Dokumentarchiv des Landtags NRW, September 11, 2018, https:// www.landtag.nrw.de/portal/WWW/dokumentenarchiv/Dokument/MMD17-3577.pdf.

64 "Protest gegen Auftritt von Mbembe," Jüdische Allgemeine, April 17, 2020, https://www.juedische-allgemeine.de/politik/protest-gegen-auftritt-von-mbembe/.

${ }^{65}$ For detailed insight into the dispute as well as the underlying conflicting structures, especially those that universalize and particularize Holocaust and colonial crimes, see Sznaider, "The Summer of Discontent."

${ }^{66}$ As examples of the structural blind spot for antisemitism within postcolonial research, see an article by Meron Mendel and Saba-Nur Cheema, "Leerstelle Antisemitismus," tageszeitung, April 25, 2020, https://taz.de/Postkoloniale-Theoretiker/!5678482/, as well as Ingo Elbe, "Die postkoloniale Schablone," tageszeitung, May 14, 2020, https://taz.de/Debatte-um-Historiker-Achille-Mbembe/!5685526/. As examples of an argument that a structural blind spot for racism exist in Germany, see Bonaventure Ndikung, Interview with Christiane Habermalz, "Debatte um Achille Mbembe ist rassistisch," Deutschlandfunk, September 9, 2020, https://www.deutsch- 
of the accusation of racism. Michael Rothberg, for example, identifies a problem within German memory culture as a whole, arguing that the central role of the Holocaust in Germany's memory culture since the 1980s results in less space for other forms of memory. Rothberg says that the criticism of Mbembe and postcolonial memory practice in general reveals a defensive attitude to forms of memory that are located "beyond residual Eurocentrism." ${ }^{67}$ According to Rothberg, the classification of challenges to the uniqueness of the Holocaust and critical approaches to Israel as "antisemitic" ultimately originate in a desire to suppress any postcolonial reappraisal of Germany's colonial history ${ }^{68}$ If one follows Rothberg's logic to its end, any critique of postcolonial memory would have to be interpreted as based in a German provincialism or eurocentrism that refuses to reappraise racism and colonialism in Germany. In that view, defending the memory of the Holocaust would naturally be an obstacle to postcolonial memory.

All three of these positions involve a kind of standoff that positions each memory form as irreconcilable with the other. This, in turn, creates a tendency to generalize about the other side, leaving little room for recognizing different positions within each form of memory. To put it bluntly, this standoff harbors the danger of imagining postcolonial memory as generally antisemitic and hostile towards Israel. On the other hand, it also harbors the danger of imagining Holocaust memory as unambiguous and conflict-free, or in the worst case, as a tool to prevent the rise of postcolonial memory in Germany.

Before the Causa Mbembe, the German scientist Astrid Messerschmidt had already pointed out the pitfalls that could result from the existing constellations of postcolonial memory and Holocaust memory in Germany. What is especially interesting is that Messerschmidt applied the idea of a break in the continuity of the past and present, which is implied by the prefix post in the word "postcolonial," to the history of National Socialism in Germany. Thus, for Messerschmidt, the current society in Germany cannot be viewed only through a postcolonial lens but also through a post-National Socialist lens. Messerschmidt suggests that even today the collectively shared thought patterns of the National Socialist past

landfunk.de/kunstkritiker-ndikung-debatte-um-achille-mbembe-ist.911.de.html?dram:article $\mathrm{id}=483358$ and an open letter from some African intellectuals, May 18, 2020, https://simoninou. files.wordpress.com/2020/05/brief-von-afrikanischen_intellektuellen_an-die-dt-bundeskanzlerin_-angela-merkel.pdf.

${ }^{67}$ Michael Rothberg, "Comparing Comparisons: From the 'Historikerstreit' to the Mbembe Affair," Geschichte der Gegenwart, September 23, 2020, https://geschichtedergegenwart.ch/comparing-comparisons-from-the-historikerstreit-to-the-mbembe-affair/.

${ }^{68}$ Ibid. 
still shape current German society, but with a different logic. ${ }^{69}$ Messerschmidt assumes, however, that it is easier to speak of a postcolonial than of a post-National Socialist Germany. The problem with labeling Germany as a post-National Socialist society can, according to Messerschmidt, be explained by the society's still-ambivalent attitudes toward war and defeat. The discontinuous process of historical reappraisal in Germany recognizes that the culpability of many parts of German society is still having effects on families today. ${ }^{70}$ Be that as it may, in parallelizing Holocaust memory and postcolonial memory, Messerschmidt says that both historical events and their underlying ideologies have left traces in Germany. Now, when it comes to remembering both historical events at the same time, Messerschmidt warns against the idea that postcolonial memory can just be added to German memory culture next to Holocaust memory. ${ }^{71}$ It is precisely the recognition that German society is a post-National Socialist one and as such is in many respects still shaped by the experience of National Socialism that prevents such a simple "plus" calculation. Rather, postcolonial memory has to be related to the memory of the Holocaust in some form of entanglement. One can visualize that entanglement as something in which the postcolonial present is shaped by self-images and world-images that are collectively based on the thought patterns of National Socialism. At the same time, the post-National Socialist present is shaped by self-images and world-images that are collectively based in the thought patterns of colonialism. ${ }^{72}$ It still remains unclear exactly how this entanglement looks in the practice of memory.

According to Messerschmidt, whenever postcolonial thinking imagines Holocaust memory to be unambiguous and even regards Holocaust memory as an obstacle to postcolonial memory, it oversimplifies the debate over remembrance of the Holocaust and National Socialism. ${ }^{73}$ Messerschmidt thus provides a counter-argument to Michael Rothberg's identification of Holocaust memory as an obstacle to postcolonial memory. It is precisely the oscillation between stability and fragility in Holocaust memory that complicates unraveling the entanglement of Holocaust memory and postcolonial memory.

${ }_{69}$ Messerschmidt, "Postkoloniale Erinnerungsprozesse," 56 and Astrid Messerschmidt, "Postkoloniale Selbstbilder in der postnationalsozialistischen Gesellschaft," FKW. Zeitschrift für Geschlechterforschung und visuelle Kultur, No. 59 (2016): 24-37.

${ }^{70}$ Messerschmidt, "Postkoloniale Selbstbilder," 34-35.

${ }_{71}$ Messerschmidt, "Postkoloniale Erinnerungsprozesse," 53.

72 Messerschmidt, "Postkoloniale Selbstbilder," 25.

73 Messerschmidt, "Postkoloniale Erinnerungsprozesse," 56-57. 
The stable side of Holocaust memory, which is shaped by the ethical imperative of accepting historical responsibility, is strangely decoupled from the current reappearance of antisemitism. In other words, even a long tradition of remembering the Holocaust and National Socialism is not preventing a resurgence of antisemitic violence. At second glance, one might ask whether the ethical imperative to accept historical responsibility for the Holocaust has developed a logic of its own that can be instrumentalized for different purposes. ${ }^{74}$ In that context, Astrid Messerschmidt points out that the German education system teaches the history of the years 1933 to 1945, but its teaching is decoupled from any discussion of its antisemitic ideological preconditions. This makes it possible for students to distance themselves from the Nazi era and thus to believe that the past has been successfully overcome, even though antisemitism is in reality still prevalent. More precisely, post-1945 antisemitism is viewed as a secondary form of antisemitism that reverses the perpetrators and the victims or suggests that the need to preserve the memory of the Holocaust is at an end. ${ }^{75}$ The ethical imperative to accept historical responsibility for past antisemitism can operate to negate or excuse one's own antisemitism because one cannot be antisemitic when German society has done so and faced up to its historical moral guilt. To sum it up: obviously, Holocaust education does not go hand in hand with education on antisemitism. The idea that the National Socialist past has been successfully overcome can also be instrumentalized to strengthen a positive national self-image that pictures Germany as a successful democratic society exactly because it has dealt with its problematic past. For Messerschmidt, this is a problem, in that not only antisemitism becomes unspeakable but so does racism, because the existence of racism contradicts the positive national self-image. ${ }^{76}$ Michael Rothberg's concern that Germans will instrumentalize Holocaust memory in order to repress postcolonial memory is not completely unthinkable anymore.

In view of this complex situation, I suggest making neither Holocaust memory nor postcolonial memory the focus of any analysis, but rather to start paying attention to the discourse of German memory culture in order to find a way out of the conflict between the two memory forms. However, the attention that I propose below is not to be understood as the same attention implied by Michael Rothberg. Instead of imagining Holocaust memory as an obstacle to postcolonial

\footnotetext{
${ }_{74}$ Messerschmidt, "Postkoloniale Selbstbilder," 31-35.

75 Ibid., 29-30.

76 Ibid., 32-33.
} 
memory, or classifying any criticism of postcolonial memory research as German Eurocentrism, I try to offer a way to stay sensitive to both.

\section{Approaching Holocaust Memory and Postcolonial Memory Through a Discursive Lens}

Holocaust memory and postcolonial memory, as well as the complex relationships between the two memory forms, essentially revolve around questions about what can be said and, above all, how it can be said. This is why I propose to look at German memory culture from a discursive angle.

The main focus of remembering the Holocaust and National Socialism in general has shifted through the decades, but at the same time certain constant verbal acts used to discuss Holocaust memory have shaped ways of speaking that have become institutionalized. That is, they have become to a certain extent established forms of speaking. ${ }^{77}$ These institutionalized forms of speaking can also be understood as strands in the broader discourse of German memory culture. According to Michel Foucault's theory of discourse, the institutional consolidation of knowledge does not happen by coincidence but on the basis of power relations built upon fields of knowledge. ${ }^{78}$ Consequently, discourse, including the discourse of German memory culture, reveals that which is accepted as the truth at a given point in time in a specific social context. If one wants to analyze how and why a certain piece of knowledge is accepted as true at a certain point in time, one has to look at the statements that are being made about it in discourse. In a nutshell, application of Foucault's discourse theory reveals that what is considered to be true and accepted at any given point in time and in any specific context is not the result of chance, but of a complex relationship between power and knowledge which manifests itself in the linguistic surface of discourse and is at the same time reproduced by the discourse. If one follows Foucault's theory of discourse, analysis of discourse does not deal with the question of how to separate true from false, but rather tries to discern the rules by which truth is endowed with power and separated from the false. Discourse

${ }^{77}$ For an understanding of the institutionalization of ways of speaking in discourse analysis, see Margarete Jäger and Siegfried Jäger, Deutungskämpfe. Theorie und Praxis Kritischer Diskursanalyse (Wiesbaden: VS Verlag für Sozialwissenschaften, 2007), 19, as well as Reiner Keller, Wissenssoziologische Diskursanalyse. Grundlegung eines Forschungsprogramms (Wiesbaden: VS Verlag für Sozialwissenschaften, 2011).

${ }^{78}$ Michel Foucault describes the complex relationship between power and knowledge in Michel Foucault, Überwachen und Strafen. Die Geburt des Gefängnisses (Frankfurt a. M.: Suhrkamp, 1994), 39. 
reveals the struggle over the status of truth. ${ }^{79}$ Accordingly, discourse analysis reveals how discourse itself regulates the statements that are being made. ${ }^{80} \mathrm{In}$ order to be able to understand what can be said about a specific field of interest and how it can be said, one must try to deconstruct the discourse in question at a given point in time.

Applying the foregoing to the conflicting constellations of Holocaust memory and postcolonial memory, I propose to place both forms of memory within the framework of a single common discourse, the discourse of German memory culture. Hereinafter, I mention some of the possibilities such a discursive approach offers for better understanding the conflicting constellations of Holocaust memory and postcolonial memory.

The first possibility arises from identifying both forms of memory as discursive strands in a broader discourse. This gives us an answer to the question of what can be said. It dissolves the argumentative standoff between the two memory forms. Instead, the discourse of German memory culture becomes the center of analysis. It becomes possible to analyze various statements about remembering the Holocaust and about remembering colonialism at the same time.

Taking the discursive side of memory culture into consideration broadens our perspective on the genesis of that culture and makes it possible to understand the relationship between recent statements about postcolonial memory and the statements that have already been institutionalized. In particular, a discourse can be imagined as a flow of knowledge through time. ${ }^{81}$ Elements of knowledge do not easily change, and some elements are retained over time. Other elements reappear in a new form, and new elements can be added to existing elements. The discourse of German memory culture can be thought of as such a flow of knowledge through time. Over time, certain ways of speaking have become institutionalized and the discourse itself has developed its own history. When postcolonial memory encounters this discourse, statements about it have to align with the already existing elements of knowledge, at least to a certain extent, in order to be heard.

The discursive perspective offers the possibility of analyzing why some statements made by the advocates of postcolonial memory are highly contested. It is because they resemble similar statements that have been lying on the border between true and false in past discourse. An example is the term

\footnotetext{
${ }^{79}$ Michel Foucault, "Wahrheit und Macht. Interview von A. Fontana und P. Pasquino," in Dispositive der Macht: Über Sexualität, Wissen und Wahrheit (Berlin: Merve, 1978), 21-54.

80 Jäger and Jäger, Deutungskämpfe, 23.

81 Ibid.
} 
Historikerstreit 2.0, which was used by Michael Rothberg to describe the Causa Mbembe. ${ }^{82}$ This discursive element refers to the old Historikerstreit and brings to mind the earlier conflicts in the contested field of Holocaust memory and the German memory culture that postcolonial thinking is entering. It draws a parallel between the older conflicts and the newer ones.

However, as I have already mentioned, when it comes to Holocaust memory one can ask to what extent the ethical imperative to accept historical responsibility has been instrumentalized to create a positive national self-image in which everyday antisemitism is unspeakable. A systematic analysis of the statements of German memory discourse will not only reveal the extent to which postcolonial remembering is regulated, but the extent to which speaking about antisemitism is regulated as well, because the appearance of discursive elements of antisemitism may contradict the image of a successful reappraisal of the National Socialist past.

The second possibility offered by a discursive lens is the chance to more deeply examine the relationship between the different forms of memory within the German cultural memory discourse and their effect on the discourse. A discursive perspective not only offers a way to gain a better understanding of the history of the discourse, but also to analyze current movements within it. That gives us an answer to the question of how the memories of the Holocaust and colonialism are expressed in relation to one another.

According to Siegfried Jäger, strategies for how to say something within a discourse include "direct prohibitions and restrictions, allusions, implicates, explicit taboos, but also ... conventions, internalizations, consciousness regulations" that narrow or expand the scope of discourse. ${ }^{83}$ At this point it is important to bring up the understanding of power according to the discourse theory of Michel Foucault. Foucault imagines power as neither static (i.e., as a fixed point that belongs to one position alone and is absent for another), nor as a destructive force. Instead, power must be understood as a productive force and as something that can be found in all places at all times. Even resistance to power is not the lack of power, but rather has to be understood as counter-power. ${ }^{84}$

82 Rothberg, "Comparing Comparisons."

83 Siegfried Jäger, "Diskurs und Wissen. Theoretische und methodische Aspekte einer Kritischen Diskurs- und Dispositivanalyse," in Handbuch Sozialwissenschaftliche Diskursanalyse, Vol. I: Theorien und Methoden, ed. Reiner Keller et al. (Opladen: Leske und Budrich, 2001), 84.

${ }^{84}$ Michel Foucault, The History of Sexuality, Vol. 1: An Introduction (New York: Pantheon Books, 1978), 92-98. 
By analyzing discourse one can pin down power relations and visualize the effects of power. The understanding of power as a relationship rather than a fixed force in the hands of one side prevents us from creating a simplified schema of dominant and suppressed forms of memory and gives us a way to visualize the fragile side of Holocaust memory. Lastly, discourse analysis makes it possible to analyze the relationship between statements that demand a postcolonial reappraisal of German colonialism and statements that warn against certain postcolonial approaches. Such an analysis might reveal points at which statements systematically and automatically contradict each other, and also where other statements cross each other unproblematically. Ultimately, discourse analysis can reveal the possibility of an interlaced memory practice while at the same time being sensitive to areas of difference.

A third possibility arises from the use of a discursive angle on the conflicting constellations of Holocaust memory and postcolonial memory. Because power is conveyed discursively, discourse analysis is also a critique of power. It questions the practices and systems of expression that form a memory culture. Power does not belong to an individual or a group, but rather should be imagined as a force which pervades an entire discourse. Therefore, a critique of power is directed in all conceivable directions. Discourse analysis can not only dissolve the argumentative standoff between Holocaust memory and postcolonial memory, but it can analyze the power relations that drive the entire discourse of a memory culture. As such, discourse analysis does not ask if either Holocaust memory or postcolonial memory has more power or less power. Rather, it asks how both memory forms are regulated through the discourse itself, meaning how the discourse shapes the conflicts between the two forms. The object of the critique of power thus becomes the discourse of German memory culture itself.

Finally, I would like to address something that goes beyond analysis of the discourse itself. Discourses are not only carriers of knowledge, but they themselves have a powerful effect. They create a first-order reality with material consequences. ${ }^{85} \mathrm{~A}$ discursive analysis of German memory culture serves not only to better understand the standoff between Holocaust memory and postcolonial memory, but also leads to a critique of the material consequences of such a discourse. More precisely, if antisemitism can only be uttered implicitly or not at all, it has real consequences for the victims of antisemitic violence. The same can be said for racism: if the discursive elements of postcolonial memory are repressed

\footnotetext{
${ }^{85}$ Jäger, "Diskurs und Wissen," 85.
} 
in order to avoid dealing with the relicts of racism within Germany, it has real consequences for the victims of racist violence.

Since postcolonial memory cannot simply be juxtaposed with Holocaust memory and since the tangled design of the memory culture of Germany has so far rather been vaguely perceived, a discursive perspective on these conflicting constellations can provide a first step toward clarity. In a sense, discourse analysis creates an inventory of the current systems of statements and logic. Ultimately, the academic and public focus in Germany should be on questioning the discourse of German memory culture itself in a self-critical manner, instead of playing off both forms of memory against each other. Therewith, I align myself with Natan Sznaider, who recently presented a detailed analysis of the conflicting constellations of memory that intersected in the Causa Mbembe. For Sznaider, a "postcritical theory leaves the 'either/or' and moves towards an 'as well/as." 86 Such an approach demands that one self-critically deal with one's own prerequisites for thinking and acting in relation to one's counterparts. ${ }^{87}$

\section{Conclusion}

In the introduction to this paper, I quoted Frank-Walter Steinmeier's speech commemorating the 75th anniversary of the end of the World War II. In it, he not only mentioned Holocaust memory as being necessary for the present and future, but also draws a parallel between democracy and the remembrance of National Socialism and the Holocaust. As I have tried to show, whether it is remembering the Holocaust or remembering colonialism, the act of remembering always serves a specific purpose and is thus not an end in itself. That is why I argue that in order to understand the conflict between the constellations of Holocaust memory and postcolonial memory in Germany one needs to understand the different purposes for which both forms of remembering are being used within the public space. If, as Steinmeier's speech suggests, Holocaust memory is being used to fulfill democratic standards, this always involves danger. One might lose sight of the fragility of the Holocaust memory, or contrarily, Holocaust memory might be used to immunize society from the need to reappraise colonial racist violence.

\footnotetext{
${ }^{86}$ Sznaider, "The Summer of Discontent."

87 Ibid.
} 
In this paper I have tried to reveal the game that the discourse of Germany's memory culture is playing. This game sometimes makes it impossible to acknowledge antisemitism and racism in equal measure and instead creates a standoff between Holocaust memory and postcolonial memory. I have therefore proposed analyzing the public discourse of German memory culture in order to understand how the statements made by both sides are structured and regulated by and within the discourse. Ultimately, this may result in an opportunity for Germany to become a post-National Socialist society and a postcolonial society at one and the same time. 